as transverse bars at right angles to the costal margin. Near the base of this wing below the cell there is a dark fuliginous mark. The spots upon the secondaries are crowded together toward the base and again toward the outer margin, leaving a clear discal band of the ground color visible. Three small round spots near the base and a quadrate bar in the outer series are conspicuous because showing no silvery pupillation and being darker in color than the rest. Anal lobe black. Palpi, legs and body concolorous. Expanse $27 \mathrm{~mm}$.

Type $\delta$ in collection of the author.

\section{A. Argyrocyclus, sp. nov.}

q. Allied to $A$. orcas, Drury, but differing widely in important particulars from the female of that species.

Upperside:-The prevalent color is dark greenish brown glossing with blue in certain lights. There is a large white spot at the end of the cell of the primaries followed by a subapical series of very small and obscure spots. Underside:-The ground color is dark orange fading upon the inner margin of the primaries into pale testaceous. The fringes are black checked with white at the tips of the nervures. The anal lobe is black. The silvery spots adorning the wings are relatively large and ringed with dark maroon. Instead of the one long spot which stands upon the primaries of $A$. orcas the fourth from the base, there are in $A$. argyrocyclus three spots grouped triangularly. Instead of the nine silver spots which appear upon the secondaries of $A$. orcas there are in $A$. argyrocyclus sixteen spots and all lying within the submarginal band of dark maroon which in both species appears upon the secondaries. Expanse of wings $40 \mathrm{~mm}$.

Type in collection of author. Pittsburg, Pa., Io Nov. I8go.

\title{
SOME GENERA OF OEDIPODIDAE RESCUED FROM THE TRYXALIDAE.
}

BY SAMUEL HUBBARD SCUDDER, CAMBRIDGE, MASS.

In his Prodromus Oedipodiorum, Saussure constructs a table for the separation of the genera of this family, in which, when he has reached the "stirps Oedipoda," afterwards termed by him Oedipodites, he first separates from the remainder of the stirps the new genus Daemonea, an extraordinary form from Peru, known to him apparently only by a single imperfect and immature specimen in Brunner's collection. This genus he found to differ from all others in the forward extension of the vertex, "faciem adumbrans," the stout form of the hind femora with slight carinae, the great length of the hind tarsi which are nearly two thirds as long as the hind tibiae, and the peculiar concave structure of the dorsal surface of the pronotum.

In a recent study of some American species of acridiodea I have been greatly puzzled by a number of forms which seemed to lie on the border land between the oedipodidae and the tryxalidae. One by one they have been removed in my collection from one family and the other without finding a 
resting place, until their comparative examination, after a general survey had been completed, showed me that they possessed features in common which warranted their being grouped together and placed as a whole in the oedipodidae, although several of them present marked Tryxaline features. I had concluded to regard them as a distinct subfamily of oedipodidae, when I dicovered that one of them, the genus Hippacris, described by me many years ago* from Peru as an exceptional form of tryxalidae, was very closely related indeed to Saussure's Daemonea, so much so that the latter genus also would have to be placed in the same category; this separate treatment, but under the name of a stirps, I believe Daemonea and Hippacris would have received at Saussure's hands, had he possessed a specimen of the latter; and to this assemblage of forms I propose to give the subfamily name of

\section{ACROLOPHITINAE.}

The distinguishing characteristic of the members of this group among oedipodidae is that the front and vertex conspire to form an advancing process, sometimes also ascending, in the upper front of the head, much as in Colpolopha among acrididae, and in many phymatidae, and of course reminding us of tryxalidae; but in such other characteristics of structure as would be regarded as more commonly found in the tryxalidae than in the oedipodidae, they almost invariably incline to the latter group; and where any one of them shows a Tryxaline feature (besides the fronto-vertical process) in any marked

*Proc. Bost. soc. nat. hist., 1875, v. 17 , p. 267. degree, it is almost sure to be offset by some other more striking Oedipodine features and often by a combination of several. As a general rule, the face is almost perpendicular below the fronto-vertical process, which with the process causes the upper portion to be more or less concave. The eyes, except in Peruvia and especially in Gymnes, are remarkably small, generally very much shorter than the infraocular portion of the genae; the antennae are linear or faintly ensiform and usually depressed on the basal joints; the metazona is always somewhat though rarely much longer than the prozona, with the posterior process subrectangulate or broadly rounded, generally with a slight median carina running through the whole pronotum, but crested on the metazona in Acrolophitus, and almost absolutely absent in the genera at the other end of the series; the prozona traversed by a pair of faintly incised continuous transverse sulci, the hinder never confused with the typical sulcus separating the prozona and metazona; lateral lobes of the pronotum with the anterior and posterior margins parallel or subparallel, except in Hippacris (and Duemonea?); the mediastinal and scapular areas in the basal half of the tegmina more or less, sometimes very, irregularly reticulate, never with simple transverse parallel veins; the vena intercalata generally obscure, sometimes wanting, the vena axillaris sometimes free, sometimes impinging on the anal vein; metasternal lobes distant (except in Peruvia).

There is no doubt that Hippacris and Daemonea are widely separated from the others and that fully to justify their collocation in this manner intermediate types should be found; these are to be sought in the western tropics of America. It should not, however, be overlooked that in the form of the lateral lobes of the pronotum Hippacri 
and Daemonea are far more Tryxaline than any of the others, for the posterior margin rapidly retreats from the very tip, so that the lobe narrows perspicuously. The features in which these two genera stand apart from the others will be seen in the following table of the genera of this group, in which I have placed all known to me.

TABLE OF THE GENERA OF ACROLOPHITINAE.

Body slender; vertex horizontal or ascending at apex, the tip bluntly pointed; frontal costa extending to clypeus; metazona above transversely convex or tectiform or plane with a median carina, never concave; lower posterior angle of lateral lobes of prothorax subrectangulate; hind legs relatively long; hind femora slender, elongate and compressed; hind tibiae with more than eight spines in the outer row; hind tarsi less than half as long as hind tibiae.

Head as viewed laterally with distinctly ascending vertex; face below fronto-vertical process subperpendicular; metazona distinctly elevated above the prozona, tumid or crested; antennae more than half as long as the tegmina.

Metazona much longer than prozona, with an elevated crest. Acrolophitus. Metazona barely longer than prozona, tumid, but with only a slight carina ........................

Head as viewed laterally with vertex scarcely or not ascending; face below fronto-vertical process distinctly though not greatly declivent; metazona hardly or not elevated above the prozona, rarely tumid, never more than gently carinate; antennae less than half as long as the tegmina.

Antennae much longer than the face ; lower margin of lateral lobes of prothorax anteriorly excised, broadly exposing the pleural plate.
Antennae entirely filiform; dorsum of metazona raised at an exceedingly small angle with that of the prozona; anterior margin of tegmina shouldered but not distinctly lobed near the base; last hind tarsal joint hardly more than half as long as the other two together.

\section{Pedioscirtetes.}

Antennae with the joints of the basal third depressed and slightly broader than beyond; dorsum of prozona and metazona in same plane: anterior margin of tegmina distinctly lobed near the base; last hind tarsal joint (at least in Machaerocera) longer than the other two joints together.

Fastigium of vertex longitudinally sulcate with no median carina; median carina of pronotum subobsolete between the sulci of the prozona; posterior margin of lateral lobes not produced posteriorly at its extremity; axillary vein of tegmina free; ulnar vein normal.

Machaerocera.

Fastigium of vertex transversely tumid with a distinct median carina in addition; median carina of pronotum equally distinct throughout; posterior margin of lateral lobes produced posteriorly at the extremity into a slight rounded lobe; axillary vein of tegmina impinging on the anal at the end of the basal third of the wing; ulnar vein approaching the median...Peruvia.

Antennae shorter than the face; lower margin of lateral lobes of prothorax 


\section{Acrolophitus Thomas.}

Body moderately slender. Head moderately large, slightly enlarging below, giving greater effect to the subconical ascending and advancing process, which is nearly as long as the eye and is formed of the extension of the front and vertex; the latter attenuate in front, forming slightly less than a right angle with the upper part of the frontal costa, the angle minutely rounded; frontal costa slender, the sides faintly converging from below upward, above the median ocellus more rapidly convergent and at extreme summit pinched to a lamina, below it sulcate, the lateral carinae of the face conspicuous throughout; fastigia obsolescent but not confounded with the vertex, their position at the convex base of the lateral ridge of the frontal process being clear but not sharply defined, the fastigia being in no way depressed, not visible from above. Lateral ocelli far removed from the margin of the vertex, close to the eyes. Eyes small, feebly prominent, not more than half as long as the infraocular portion of the genae. Antennae half as long again as head and prothorax together, nearly as long as the hind femora, rather coarse, the first joint nearly twice as long as broad, but little stouter than the succeeding, the joints of the apical half or more punctate.

Prothorax with the prozona quadrate with parallel sides, the dorsum depressed $b u_{t}$ transversely and gently arched, the metazona tapering slightly forward, the dorsum tectiform and strongly crested, - this with the elevated head giving it a strong selliform aspect; prozona with the median carina very obscure, distinctly intersected not only by the typical sulcus (which is thrust forward by the metazonal crest) but also by two additional sulci, between which the carina is entirely obliterated; metazona strongly and roundly crested, the hind margin rectangulate, the lateral carinae distinctly intersected by the typical sulcus, which extends normally into the lateral lobes; these have the pos- terior angle rectangulate, the lower margin obtusely angular, its hinder portion horizontal, its anterior obliquely ascending; metasternal lobes in $\delta$ nearly, in $q$ fully, as far apart as the mesosternal, both quadrate or transversely quadrate. Tegmina almost uniformly coriaceous throughout but feebly membranaceous apically, moderately slender, rather densely reticulate, supplied normally with spurious veins, the vena intercalata vague or lacking, the vena media and vena discoidalis both furcate, the vena axillaris independent. Radiate veins of anal field of wings normal, not incrassate. Hind femora slender, longer than the abdomen; spurs of hind tibiae strong, curved, arcuate, of considerable length but the inner scarcely two thirds as long as the first joint of the tarsi, which are of normal length.

These characteristics, apart from the pointed head, seem to show the nearest relation to Leptoternis, Conipoda and allied genera of the Old World; but Acrolophitus is still far removed from them, and though not so extraordinary a form as Saussure's Daemonea from South America, certainly shows many features which recall that strange type, and forms one link in a series connecting the typical oedipodinae therewith.

I know of but one species of the genus, $A$. hirtipes, first found by Say on the upper Arkansas and since reported from near Cañon City, Colorado, and Fort D. A. Russell, Wyoming (Thomas), and southern Colorado (Carpenter), and taken in Colorado 500' (Morrison), between Lakin, Western Kansas, and Pueblo, Col., July 8-9, r877 (Scudder), at Pueblo, Col., July 8-9 and August 30-31, I877 (Scudder), Meridian Creek, Tex., June 6, "very rare, found among bushes" (Belfrage), and 
Pecos River, Tex. (Capt. Pope). Mr. $P$. R. Uhler has also given me specimens from Kansas and Texas. It seems to have been oftenest taken near its first known locality, on the upper Arkansas, east of the mountains.

The next genus mentioned in the table is closely allied to the preceding, but departs in a greater degree from the Oedipodine type. Except for lacking a metazonal crest on the pronotum, it bears indeed a striking resemblance to Acrolophitus, a resemblance which is most marked in the strange form of the head in both. The points, however, in which it further departs from the normal Oedipodine type are not many and may be summed up as follows: The prozona and metazona are of equal length, the latter obtusely and roundly angulate behind, the angulation scarcely perceptible; the basal third or fourth of the marginal area of the tegmina is reticulate indeed, but the reticulation is sometimes mostly made up of crowded transverse veinlets interlinked by inosculating longitudinal veins; and the axillary vein unites with the anal by the end of the basal fourth of the wing, much as in Tropidolophus. It does not appear to have been described, and may be characterized as follows.

\section{Acrocara (äkpos, kápa) gen. nov.}

Body slender, subfusiform. Head of the same general form as in Acrolophitus, but somewhat more slender and with the frontovertical process sometimes somewhat more advanced; the vertex attenuate and conical in front, slightly declivent at extreme tip, forming in general considerably less than a right angle with the upper, gently convex portion of the frontal costa; its upper surface is plane or plano-convex; frontal costa very similar to that of Acrolophitus but not so strongly compressed above the ocellus and compressed more uniformly and over a broader area, allowing the median sulcus to extend to the vertex though as slender as possible in the compressed portion; its sides are also less regularly convergent, being either disturbed by a rounded divergence, just above the extreme base, which just fails of reaching the clypeus or else parallel below; lateral carinae of the face moderate, straight, divergent; fastigia and lateral ocelli as in Acrolophitus. Eyes small, not very prominent, a little longer then half the infraocular portion of the genae. Antennae twice as long as the head and thorax together, longer than the hind femora, moderately coarse, the first joint as in Acrolophitus, the succeeding joints cylindrical and equal and the joints of the apical two thirds punctate $(\delta)$, or a little more than half as long again as head and thorax together, shorter than the hind femora, the joints beyond the basal sometimes depressed and then tapering to the apex ( $q)$.

Prothorax with the prozona subquadrate with parallel sides, the dorsum not depressed but regularly arched transversely, in the $q$ with a slight tendency to be tectiform, the metazona tapering strongly forward and slightly tumid, the dorsum depressed but slightly tumid, this tumidity with the elevated head giving the whole a somewhat selliform aspect; prozona with the median carina subobsolete, distinctly intersected not only by the exactly transverse, typical sulcus, but also by two additional sulci, between which the carina is sometimes entirely obliterated; metazona with a distinct but slight and uniform median carina fading at the extremities, the hind margin obtusely and roundly angulate, the lateral carinae distinctly intersected by the typical sulcus which extends normally into the lateral lobes; 
these have the posterior lower angle rectangulate, the extreme angle rounded, the lower margin barely angulate, the hinder portion subhorizontal, its anterior slightly ascending; metasternal lobes in $\delta$ about three fourths as far apart as the mesosternal, in the $q$ as far a part, subquadrate with convex sides. Tegmina slender, coriaceous throughout, but nowhere densely and less densely apically, rather densely reticulate on the basal half, normally supplied with spurious veins, the vena intercalata rather feeble and irregular but present, the vena media and vena discoidalis both furcate, the vena axillaris impinging on the vena analis. Radiate veins of anal field of wings normal, not incrassate. Hind femora slender; longer ( $\delta$ ), or slightly shorter ( $q$ ), than the abdomen; spurs of hind tibiae as in Acrolophitus; hind tarsi of normal length.

It will be seen from these details, that, notwithstanding the different character of the dorsal portion of the metazona the close relationship of Acrocara and Acrolophitus is clear. Two specimens are known to me, which may be separated as follows :-

Lateral margins of frontal costa convergent at base; fastigium of vertex as viewed above not projecting beyond the middle of the eyes by more than their distance apart at this point; middle half of wing occupied by a broad dark band..........pulchellum.

Lateral margins of frontal costa convergent at base; fastigium of vertex as viewed above projecting beyond the middle of the eyes by considerably more than their distance apart at this point; almost the entire wing dark................maculipenne.

Bruner's Pedioscirtetes pulchella (Proc. U. S. nat. mus., I89o, v. I2, $60-61$, pl. I, fig. 10) of which he has considerately sent me the female type for examination, belongs in this genus; the other species has not before been described.

\section{ACROCARA MACULIPENNE.}

\section{Pedioscirtetes maculipennis Bruner,} Ms.

Dull brownish olive green; head, thorax, and legs sparsely and thinly pilose. Head dull shining silvery white with a faint greenish tinge; two obliquely vertical pale green bands pass downward and more or less backward from below the eye and from the posterior margin of the same, the former fading and dispersed below; vertex with a similar broad median band, merging into dark brown anteriorly; frontal carina luteous, the sulcus infumated below and more or less greenish. Antennae blackish brown, the apical and basal joints and the inner side of the impunctate joints reddish luteous. Prothorax with the dorsum olivaceo-fuscous, both front and hind margins and lateral carinae rather broadly ferrugineo-testaceous, the latter sometimes becoming pallid on the prozona; lateral lobes with varying shades of brown and olivaceous, the whole margin testaceous, the prozona with inferior and median pallid longitudinal stripes of varying width. Tegmina mottled with light and dark brown, the former prevailing on the basal, the latter on the apical half, arranged on the basal half in transverse, irregular, on the apical half in subparallel, oblique blotches and bars. Wings blackish fuliginous with a slight olivaceous tint, glistening and with purplish reflections, the extreme base like the basal half of the dorsum of the abdomen bronze green, the extreme tip narrowly margined with sordid white, the veins everywhere black and in the anal area narrowly margined with pallid. Hind femora with two strongly oblique, rather broad pale bars; hind femora dull luteous, obscurely banded with fuscous in the middle, next the base, and at the apex, the apical half of the spines black. Other legs obscure 
fuscous, often with a greenish tinge, with the basal half of the femora paler.

Length of body (ठَ) $27.5 \mathrm{~mm}$., (q) 35 $\mathrm{mm}$.; tip of head to tip of closed tegmina 36 $\mathrm{mm}$.; of tegmina ( $\delta$ ) $27 \mathrm{~mm}$. , ( $q$ ) $29 \mathrm{~mm}$; of hind femora ( $\delta$ ) $16.5 \mathrm{~mm}$. , ( 6 ) $18 \mathrm{~mm}$.; of antennae (ठ) $21 \mathrm{~mm}$., (q) $15 \mathrm{~mm}$.

Two 8. Montelovez, Cohahuila, Mexico, September 20 (E. Palmer); one $\$$, Lerdo, Mexico, November (L. Bruner).

The succeeding genus has a still more Tryxaline appearance, due principally to its more oblique face, which shows on a side view but little concavity below the fronto-vertical process. Whether it belongs in the tryxalidae or not, its close alliance to the preceding forms cannot be doubted. It has already been described, but insufficiently, by Thomas, who placed it with the tryxalidae, and it is here recharacterized.

\section{Pedioscirtetes Thomas.}

Thomas wrote the name Pedioscertetes, but this is incorrect, as it is plainly derived from okıртаw.

Body slender, feebly fusiform. Head of the same general form as in Acrocara, but with the vertex nearly horizontal, the process barely ascendant, the process separated from the vertex by a distinct but not deep transverse arcuate sulcation striking the anterior border of the eyes; the vertex is gently convex transversely, the process slightly tumid above; frontal costa much as in Acrocara, but with a shallower sulcus which terminates above where the costa, over a brief space, becomes compressed to a thick lamina, and with a broader and more regular divergence at base; lateral carinae as in Acrocara, as also the fastigia and lateral ocelli. Eyes small, not very prominent, about two thirds as long as the infraocular portion of the genae. Antennae (now broken in the only specimen seen) said by Thomas to extend "about one fourth their length beyond the pronotum," linear, and cylindrical except that six or seven joints beyond the second are slightly depressed and shorter than the succeeding punctate joints without gaining noticeably in breadth.

Pronotum tapering gently forward, more conspicuously on the metazona than on the prozona. the former very slightly ascending posteriorly, the dorsum of the prozona broadly convex transversely, that of the metazona nearly plane; median carina slight, slightest on the prozona, subobsolete between the sulci of the same, the two sulci of the prozona faint but complete; hind margin of metazona very obtusely angulate, the angle rounded, the lateral carinae much as in Acrocara; lateral lobes much as there with the anterior border slightly sinuate; metasternal lobes almost as far apart in the $q$ as the mesosternal. Termina slender, subcoriaceous on basal third only, where they are densely reticulate, normally supplied with spurious veins, the vena intercalata only indicated in the middle of its normal course, the vena media and vena discoidalis bath furcate, the vena axillaris impinging on the vena analis. Radiate veins of wings normal. Hind femora longer than the abdomen; spurs and hind tarsi as in Acrocara.

Only a single species is known, $P$. nevadensis Thom., from Nevada, one of the type-specimens of which has been obligingly sent me for examination by Dr. Riley. The wing is not well described by 'Thomas, nor well figured by Glover, and in the specimen seen is not fully spread, so as to render a good description impossible in its present condition. It may be said, however, that the band is fusco-fuliginous, broader 
than figured by Glover, becomes obscure and paler toward the costal margin, where it is traversed by pallid crossveins, and has the interior margin at this point limited by the divarication of the discoidal vein.

The fourth genus, Machaerocera Saussure, is a common form in Mexico, and need not detain us here. It shows no elevation of the metazona whatever.

The fifth genus of the table is founded upon a species from Peru, which I formerly described as a Machaerocera, but which must be separated from it, its distinctive features being shown in the previous table. It may be called

\section{Peruvia gen. nov.}

Body slender, subequal, compressed. Head moderately stout, trigonal. Vertex, including fastigium, gently and regularly convex, both longitudinally and transversely, with a distinct and equal median carina its entire length; triangular fastigium advanced in front of the eyes as far as their separation, the converging sides margined, the tip rounded; front considerably and almost uniformly declivent, faintly convex in front of the antennae, forming above a right angle with the vertex; frontal costa moderately broad, slightly expanding at the antennae, with subparallel sides, a little divergent below, with a broad and deep sulcus; lateral carinae prominent, parallel in upper half, considerably divergent in the lower; lateral ocelli next the eyes separated from them by their own width at the termination of the lower edge of the carinate margin of the fastigium of the vertex. Eyes semiglobular, prominent, equal, or perhaps a little more than equal, in width to the infraocular portion of the genae; beneath the middle of the eyes a short vertical carina which fades before reaching them. Antennae moderately slender, the six joints beyond the second depressed (beyond broken).

Prothorax compressed with parallel sides, the dorsum plano-subtectiform, with a strong subequal median carina throughout; prozona fully as long as the metazona, with parallel, slight, irregular, lateral carinae which are not far removed from the middle of either side; it is traversed by two straight transverse sulci which cut the carinae, but the anterior of which does not extend upon the lateral lobes, being supplanted by another in advance of it; metazona with scarcely more than should dered lateral canthi, its posterior margin angulate at a little more than a right angle; lateral lobes with normal sulci, the anterior and posterior margins subparallel, the lower posterior angle rectangulate but with a slight posterior lobe, the lower margin horizontal in its posterior half and anterior fourth, the second fourth oblique exposing the pleural plate, which shows a small descending lobe at its anterior end. Metasternal lobes of female only a little more than half as distant as the mesosternal, marked inwardly by two profound pits. Tegmina moderately slender, the anterior margin with a distinct lobe at the end of the basal fourth, subcoriaceous throughout but nowhere closely reticulate except at the extreme base and on the costal and anal margins; no intercalary vein; ulnar vein approaching the median and widely separated from the posterior ulnar; median vein simple, axillary vein impinging on the anal. Wings with humeral field very broadly scalariform, the radiate veins below normal.

The single species known to me is $P$. nigromarginata from the Peruvian Andes, described by me (Proc. Bost. soc. nat. hist. I 875 , v. 17, p. 268) as a species of Machaerocera. It is of small size.

The last genus in this division of the acrolophitinae is founded upon a single female specimen, not in the most satisfactory condition, from California. 


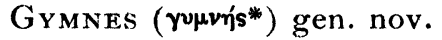

Body rather slender, compressed. Head relatively rather large, no broader beneath than above, as a whole nearly twice as high as broad, when viewed in front; vertex gently convex, transversely and longitudinally, the curve of the latter terminating at the front edge of the eyes, in front of which the fastigium is horizontal; the latterdeeply and broadly sulcate with distinct bounding walls which are parallel on the hinder, convergent on the front half, the front strongly rounded; a median carina runs through the entire length of the fastigium, most distinct on the anterior half; face subdeclivent, more strong$1 y$ in front of the eyes than below, the upper part of the frontal costa forming with the fastigium of the vertex less than a right angle; frontal costa rather narrow, pinched at extreme summit to a mere lamina, below subequal, slightly contracted immediately below the ocellus, slightly sulcate throughout except on the lamina; lateral carina straight, sharp, regularly divergent, extending to the edges of the clypeus; lateral ocelli situated midway between the antennae and the upper corner of the eyes, the fastigia facing more outward than downward or forward. Eyes twice as high as broad, considerably longer than the infraocular portion of the genae. Antennae very short, only as long as the head and half the pronotum, moderately stout, all the joints beyond the second excepting the apical equal, pretty strongly depressed, punctate, the apical joint half as broad, bluntly conical.

Prothorax with the prozona and metazona of subequal length, the former of equal width, rounded subtectiform transversely, the latter tumid and tapering forward considerably; median carina slight but distinct throughout, somewhat subdued on the posterior half of the prozona; lateral carinae on the metazona only terminating at the normal sulcus; two slight but continuous and gently sinuate

\footnotetext{
* In allusion to the very short subensiform antennae.
}

transverse sulci on the prozona, the anterior not passing into the lateral lobes; these have the anterior and posterior margins straight, slightly convergent, the lower posterior angle rectangulate but rounded, the lower margin horizontal, barely inclined upwards anteriorly, so that the plate below is scarcely at all exposed. Metasteinal lobes transversely quadrate, scarcely nearer together than the mesosternal lobes ( $q$ ). Tegmina slender, slightly tapering, scarcely coriaceous excepting at the extreme base where only the reticulation is at all dense, being elsewhere very open. Mediastinal area almost entirely free from cross nervures or reticulation of any kind except apically; intercalary vein present, discoidal vein unbranched, axillary vein impinging on the anal. Wings not large. simple and normal. Hind legs long and slender, the superior and inferior carinae of the femora well developed; hind tibiae with a dozen spines in the exterior row; cal. caria moderately long; basal joint of hind tarsi not more than twice as long as second.

A single species is at hand.

\section{Gymnes punctatus sp. nov.}

Pallid, apparently yellowish green in life. Almost entirely immaculate, the only dark markings of the body being the obscure brownish fuscous median carina of the pronotum, and the blackish fuscous posterior third of the metazona. Tegmina with six or eight small, roundish, brownish fuscous spots arranged by pairs transversely at tolerably regular intervals beginning at the middle of the basal half. Wings very delicate, translucent. Hind femora with slight narrow infuscations beyond the middle and at tip; spines of hind tibiae black-tipped.

The surface is generally nearly smooth, and a little lustrous on the pronotum which is also feebly and rather delicately punctate especially on the metazona, the lateral lobes being quite smooth on the prozona; the sides of the head are also feebly subrugose but 
none the less shining, and the lower part of the face is slightly punctate.

Length of body $17 \mathrm{~mm}$.; including closed tegmina $2 \mathrm{rmm}$; of antennae, $4.5 \mathrm{~mm}$; tegmina $15.5 \mathrm{~mm}$; hind femora $12 \mathrm{~mm}$.

Unfortunately I have but a single specimen, the colors bleached from immersion in alcohol. It is a $q$ and was taken at Tighes, California, I believe during one of the explorations under Capt. Wheeler.

There remain the genera of the other division of acrolophitinae which by their gross form, hollowed dorsum of the metazona, long hind tarsi, and short frontal costa, are widely separated from the genera we have considered. Of these I know Daemonea only from Saussure's description, and can only refer thereto, but of

\section{Hippacris Scudder,}

established on a Peruvian insect, I have before me two species closely resembling each other and yet widely distinct, which may be distinguished as follows :-

Antennae (of $q$ at least) nearly or quite half as long again as head and pronotum together, tapering regularly; tegmina relatively slender, being fully four times as long as broad; plates of the ovipositor of normal form ........................ crassa. Antennae (of. $q$ at least) apparently not much longer than head and pronotum together, several neighboring joints in two groups near the middle enlarged and depressed, forming broader areas; tegmina relatively stout, being less than three times as long as broad; plates of the ovipositor reduced to simple, straight, tapering, compressed laminae without armature

picticornis.
To the first species, $H$. crassa, described by me (Proc. Bost. soc. nat. hist., 1875 , v. 17, p. 268) from the eastern slope of the Peruvian Andes, I have nothing to add, as the single female then seen is still the only one known to me. The other from the opposite side of the Andes may be called

\section{Hippacris PICTICORNIS sp. nov.}

Nearly uniform dull leaf brown. Head punctate, but obscurely excepting on the lower half. Antennae brownish luteous, with the first and second, ninth and tenth, thirteenth to sixteenth and most of seventeenth joints black, the basal joint brownish luteous on the inner: upper surface, the ninth and succeeding joints punctate and of these the black joints depressed and wider than the others. Pronotum with the crested lateral carinae of the prozona and the hinder edge margined with black, and just above the posterior lower angle of the lateral lobes a small round luteous spot margined with blackish. Tegmina with all the longitudinal veins, except in the apical fourth, luteous. Wings faint fuliginous, all the veins blackish fuscous, and a blackish fuliginous cloud along the edges of the tip. Hind femora blackish at extremity on the outer side; hind tibiae luteo-fuscous, the spines dull luteous, blacktipped, the tarsi dull luteous.

Length of body $31 \mathrm{~mm}$.; including closed tegmina $36 \mathrm{~mm}$.; of antennae (broken beyond I th joint) $17 \mathrm{~mm}$.; of tegmina $26 \mathrm{~mm}$.; width of same in middle ro $\mathrm{mm}$. ; hind femora $15.5 \mathrm{~mm}$.; tibiae $13 \mathrm{~mm}$.; tarsi $8 \mathrm{~mm}$.

Upper Amazons, Brazil. One $\$$.

The most remarkable thing about this species is the manner in which it differs from the other species and indeed from all acridiodea I have examined in the structure of the ovipositor. Normally, 
as is well known, these parts are principally composed of an upper and a lower pair of oppositely curved, stout, falcate hooks, serving as scrapers, working in opposite directions in boring or rather scratching a vertical hole in the earth in which to deposit eggs. Plainly the oviposition of this creature must be something quite different and very likely analogous to that of the locustodea, for these hooks or scrapers are reduced to a couple of sets of straight, compressed, tapering, bluntly pointed laminae, entirely without serrations or armature of any kind, and attingent only at tip, the upper pair the larger. They would appear to be useful only in crowding eggs into already existing crevices of wood or bark. Such a difference in sexual armor between two closely allied species I have never before seen.

Another point of interest in the species is the somewhat unusual contrasts of color and somewhat vivid color, especially in the antennae, in an insect which otherwise by its monochrome of dead leaf brown would seem to be gaining defence by avoiding vividness and contrast. Such are some of the anomalies in nature.

\section{LOWNE's ANATOMY OF THE Blow-Fly.}

The first part of Lowne's Anatomy, Morphology and Development of the Blow-fly has just appeared. The prospectus an. nounced five quarterly parts each with about 64 pages of letterpress four plates and some 20 original drawings. As usual, however, the first part runs beyond anticipations, containing 98 pages. The introductory matter of 31 pages gives a life history of Calliphora, an introduction to insect anatomy in general and the broad characteristics of the Diptera and its subdivisions; while the body of the part is given up to the anatomy of the larva; half a dozen brief topical bibliographies are scattered through the Part and a brief appendix gives methods for histological work.

Hydrocyanic Acid Secreted by PolyDESMUS VIRGINIENSIS, DRURY.

Guldensteeden-Egeling has shown (Pflüger's Archiv f. d. ges. physiol., I882, v. 28) that Paradesmus (Fontaria) gracilis, Koch, a myriopod indigenous to the Fiji Islands, Moluccas, etc., but which has now become acclimatized in some of the hot-houses of Europe, produces a secretion that contains besides benzaldehyd free hydrocyanic acid. In the same year Weber (Archiv f. mikr. anat., v. 21.) showed that the repugnatory glands which produce the secretion open near the median dorsal line on certain segments and that it is only from these segments tha the characteristic odor of prussic acid is diffused. Haase in a recent note from which I have taken these bibliographical references, has again called attention to this curious secretion. (Sitzungs b. d. Gesell. naturf. Freunde zu Berlin, Jahrgang I889, p. 97.)

While collecting specimens of our native Polydesmus (Fontaria) virginiensis, a myriopod not uncommon in some parts of Wisconsin and probably in many of the middle states, I observed that when roughly handled they emitted an odor like bruised peach-leaves or cyanide of potassium. Suspecting the presence of a secretion like that of the Moluccan species, I requested a professional chemist, Mr. Davenport Fisher of Milwaukee, to test the myriopods for free hydrocyanic acid. $\mathrm{Mr}$. Fisher succeeded in establishing the presence of a small quantity of the highly poisonous substance. Subsequently I found it easy to make the test for myself. A few of the polydesmi were ground up in a mortar with a small quantity of water A few drops of potassium hydrate and ferrous sulphate were then added to the solution obtained by filtering the mass. On the application of gentle heat and the further addition of a little ferric chloride with sufficient hydrochloric acid to dissolve the precipitated ferrous and ferric hydrates, the faint but distinct tinge of Prussian blue attested the presence of free hydrocyanic acid.

W. M. Wheeler. 

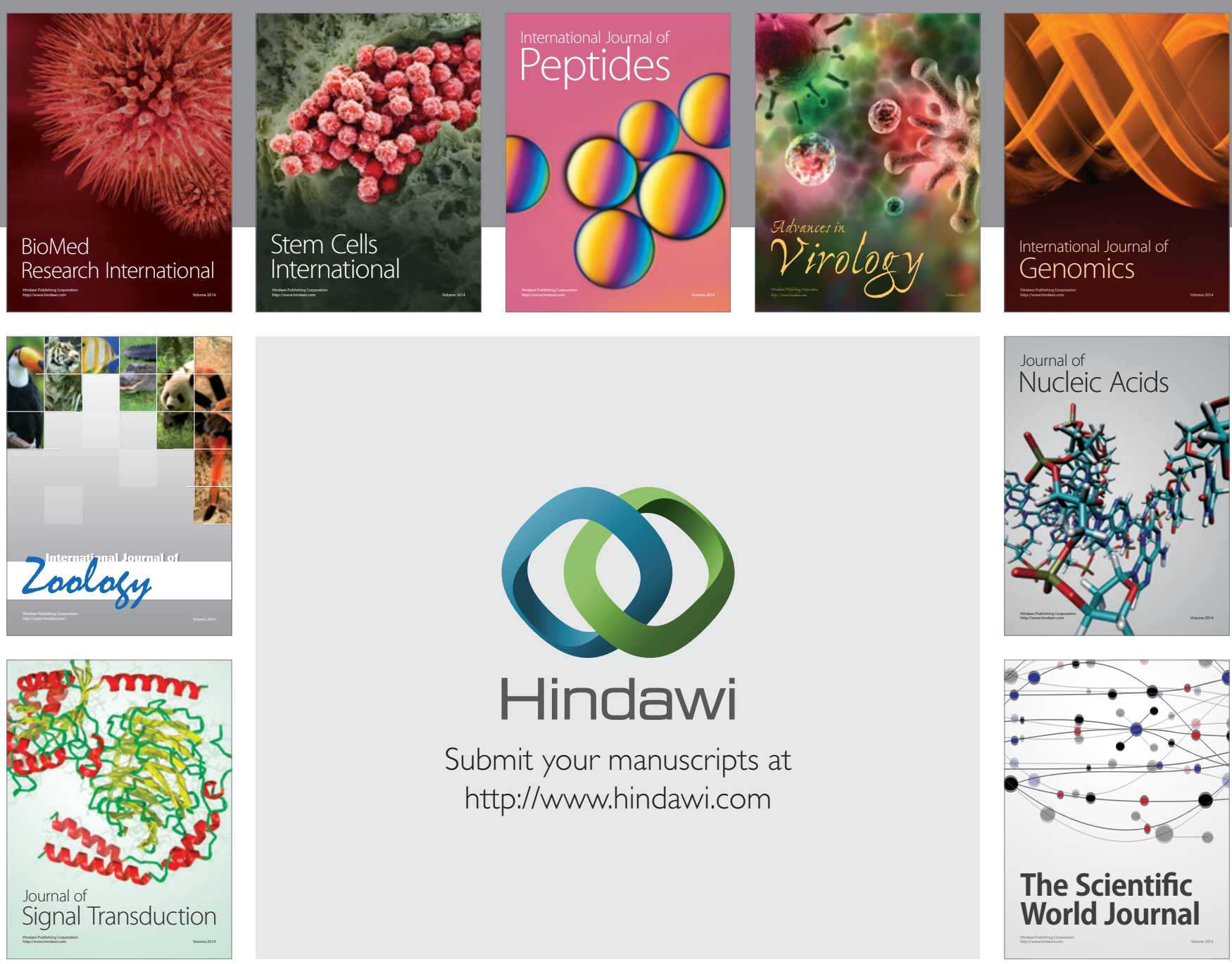

Submit your manuscripts at

http://www.hindawi.com
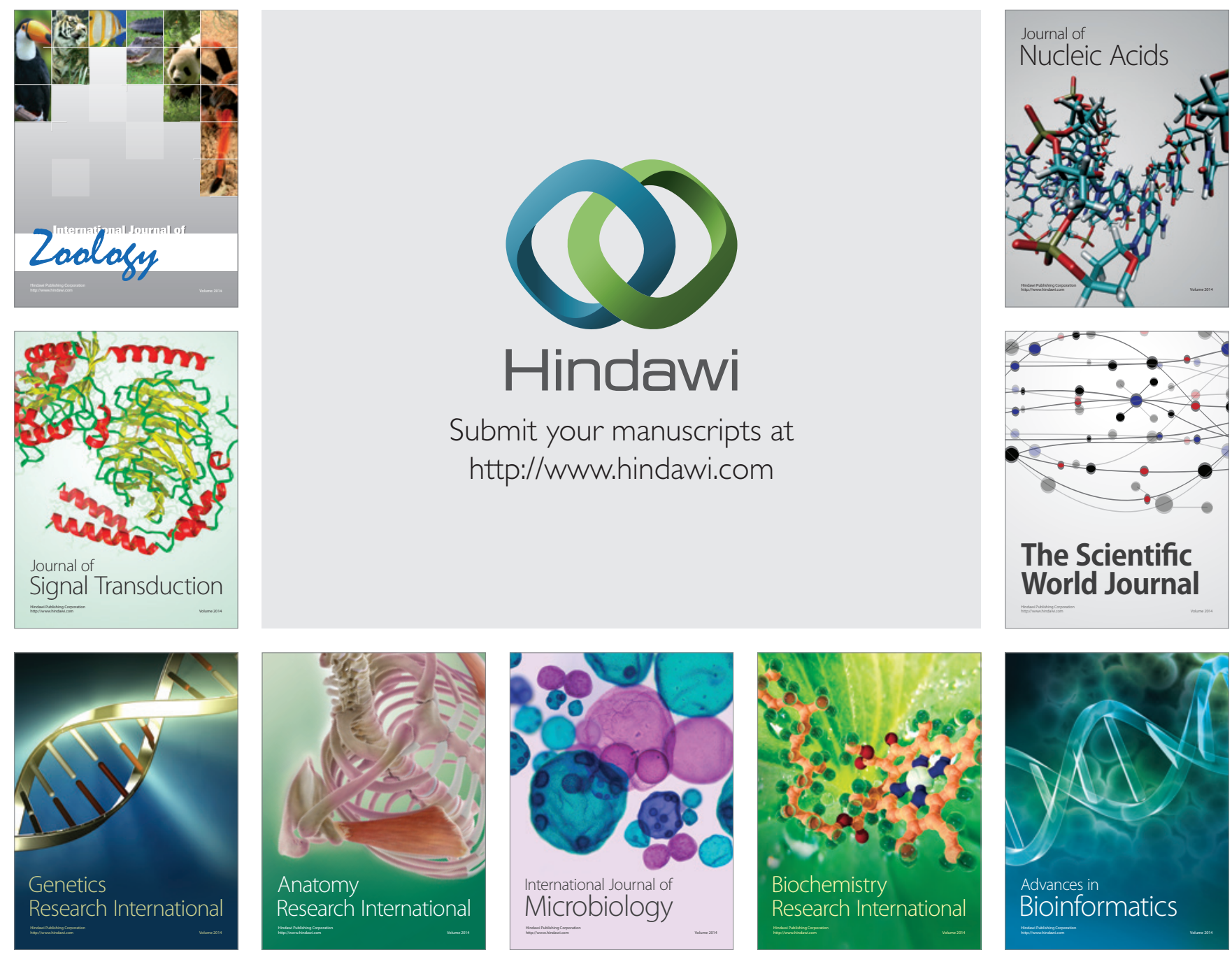

The Scientific World Journal
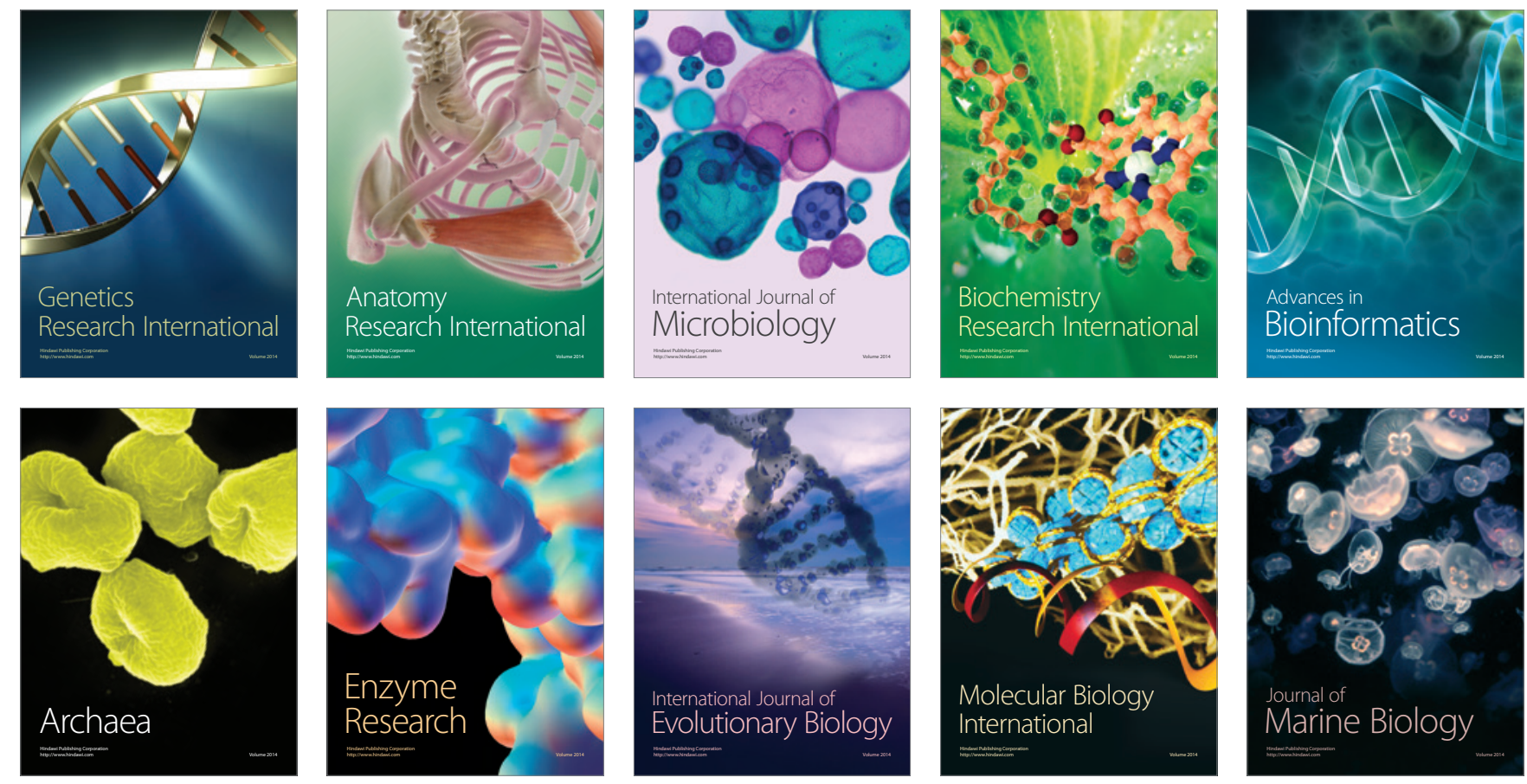